\title{
Ecological Implications of Laurel Wilt Infestation on Everglades Tree Islands, Southern Florida
}

Open-File Report 2014-1225 



\section{Ecological Implications of Laurel Wilt Infestation on Everglades Tree Islands, Southern Florida}

By James R. Snyder

Open-File Report 2014-1225

U.S. Department of the Interior

U.S. Geological Survey 


\section{U.S. Department of the Interior \\ SALLY JEWELL, Secretary}

\section{U.S. Geological Survey \\ Suzette M. Kimball, Acting Director}

U.S. Geological Survey, Reston, Virginia: 2014

For more information on the USGS—-the Federal source for science about the Earth, its natural and living resources, natural hazards, and the environment-visit http://www.usgs.gov or call 1-888-ASK-USGS (1-888-275-8747)

For an overview of USGS information products, including maps, imagery, and publications, visit $h t t p: / / w w w . u s g s . g o v / p u b p r o d$

To order this and other USGS information products, visit $h$ ttp://store.usgs.gov

Any use of trade, firm, or product names is for descriptive purposes only and does not imply endorsement by the U.S. Government.

Although this information product, for the most part, is in the public domain, it also may contain copyrighted materials as noted in the text. Permission to reproduce copyrighted items must be secured from the copyright owner.

Suggested citation:

Snyder, J.R., Ecological implications of Laurel Wilt infestation on Everglades Tree Islands, southern Florida: U.S. Geological Survey Open-File Report 2014-1225, 18 p., http://dx.doi.org/10.3133/ofr20141225.

ISSN 2331-1258 (online) 


\section{Contents}

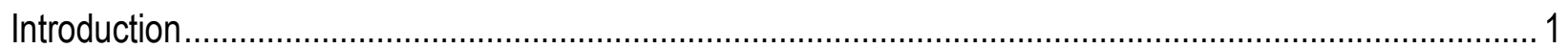

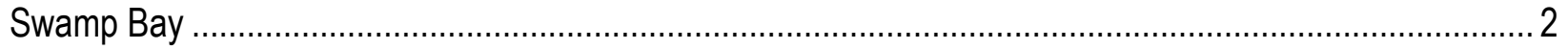

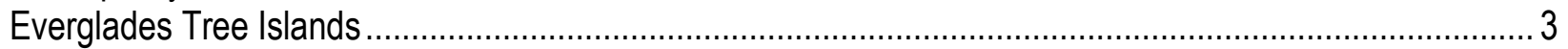

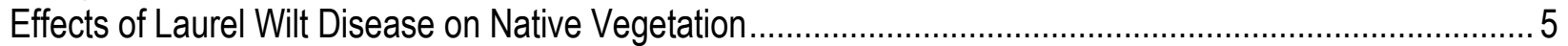

Prognosis for Swamp Bay and Everglades Tree Islands .................................................................... 8

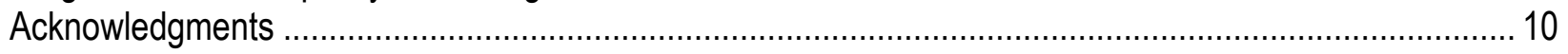

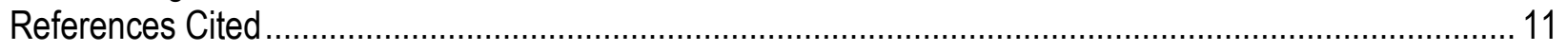



\section{Figures}

Figure 1. Graph showing cumulative percentage (\%) of red bay mortality by diameter class (diameter at breast height) on five 0.08-hectare plots at Fort George Island, Florida, July 2005-January 2007. 6

Figure 2. Graph showing total number and status of live red bay genets sampled from six 1-hectare forest plots on St. Catherine's Island, Georgia, 2004-09.

\section{Conversion Factors}

Inch/Pound to SI

\begin{tabular}{lcl}
\hline \multicolumn{1}{c}{ Multiply } & \multicolumn{1}{c}{ By } & \multicolumn{1}{c}{ To obtain } \\
\hline inch (in.) & 2.54 & $\begin{array}{l}\text { centimeter (cm) } \\
\text { millimeter (mm) }\end{array}$ \\
inch (in.) & 25.4 & \\
\hline MI to Inch/Pound & & \multicolumn{1}{c}{ To obtain } \\
\hline \multicolumn{1}{c}{ Multiply } & \multicolumn{1}{c}{ By } & inch (in.) \\
\hline centimeter (cm) & 0.3937 & foot (ft) \\
meter (m) & 3.281 & acre \\
hectare (ha) & 2.471 &
\end{tabular}


This page left intentionally blank 


\title{
Ecological Implications of Laurel Wilt Infestation on Everglades Tree Islands, Southern Florida
}

\author{
By James R. Snyder
}

\section{Introduction}

There is a long history of introduced pests attacking native forest trees in the United States (Liebhold and others, 1995; Aukema and others, 2010). Well-known examples include chestnut blight that decimated the American chestnut (Castanea dentata), an extremely important tree in the eastern United States, both as a food source for wildlife and humans and for the wood; Dutch elm disease that attacks native elms (Ulmus spp.), including those commonly planted as shade trees along city streets; and the balsam wooly adelgid (Adelges piceae), an insect that is destroying Fraser firs (Abies fraseri) in higher elevations of Great Smoky Mountains National Park. Laurel wilt, a fungal disease transmitted by the redbay ambrosia beetle (Xyleborus glabratus), is a 21st-century example of an introduced forest pest that attacks native tree species in the laurel family (Lauraceae) (Mayfield, 2007; Hulcr and Dunn, 2011).

The introduction of laurel wilt disease has been traced to the arrival of an Asian ambrosia beetle (Xyleborus glabratus) at Port Wentworth, Georgia, near Savannah, in 2002, apparently accidently introduced in wooden shipping material (Mayfield, 2007). Within the next 2 years, it was determined that the non-native wood-boring insect was the vector of an undescribed species of fungus, responsible for killing large numbers of red bay (Persea borbonia) trees in the surrounding area. Dispersing female redbay ambrosia beetles drill into live trees and create tunnels in the wood. They carry with them fungal spores in specialized organs called mycangia at the base of each mandible and sow the spores in the tunnels they excavate. The fungus, since named Raffaelea lauricola (Harrington and others, 2008), is the food source for adults and larvae. The introduction of Raffaelea lauricola causes the host plant to react in such a way as to block the vascular tissue, resulting in loss of water conduction, wilt, and death (Kendra and others, 2013).

Although first seen in red bay, laurel wilt disease also kills other native trees that are members of the laurel family, including swamp bay (Persea palustris), silk bay (Persea borbonia var. humilis), and sassafras (Sassafras albidum), as well as the economically important cultivated avocado (Persea americana) (Fraedrich and others, 2008). This paper is concerned primarily with swamp bay, an important component of Everglades tree islands. 
The spread of the redbay ambrosia beetle and its fungal symbiont has been very rapid, exceeding model predictions (Koch and Smith, 2008); by 2011, laurel wilt disease was found from the southern coastal plain of North Carolina to southern peninsular Florida. The first redbay ambrosia beetle was trapped in Miami-Dade County in March 2010, and laurel wilt disease was discovered in swamp bays in February 2011 and in commercial avocado groves about a year later (Kendra and others, 2013). By 2013, laurel wilt disease was seen in swamp bays throughout the southern Everglades in Everglades National Park, Big Cypress National Preserve, and Water Conservation Areas (WCAs) 3A and 3B (Rodgers and others, 2014).

\section{Swamp Bay}

There is considerable ambiguity in the literature regarding the naming of bay trees in the genus Persea (Coder, 2007). Some taxonomic authorities make no distinction between red bay and swamp bay and refer to both wetland and upland bays as Persea borbonia (L.) Sprengel. This includes Radford and others (1968), whose manual for the Carolinas was the leading manual for the Southeast for many years, as well as Correll and Correll (1982) in their Flora of the Bahama Archipelago. Little (1979) recognized swamp bay as a variety of red bay, Persea borbonia var. pubescens (Pursh) Little. Long and Lakela (1976), in their manual for southern Florida, recognized swamp bay as a separate species, Persea palustris (Raf.) Sarg., and most recent floras do the same (for example, Wofford, 1997; Wunderlin, 1998; Wunderlin and Hansen, 2008).

In the taxonomic treatments that recognize separate species, Persea borbonia, red bay in the narrow sense, is an evergreen shrub or small tree that is present mainly in elevated sites and has leaves with little pubescence on the back, whereas Persea palustris, swamp bay, is present in wet sites and has pronounced pubescence on the underside of leaves. Swamp bay is an evergreen shrub or small tree that can reach about $12 \mathrm{~m}$ in height (Nelson, 1994). The lanceolate leaves are 5-20 cm long and the fruit is a globose drupe about $1 \mathrm{~cm}$ long and dark blue-black when ripe. In southern Florida, swamp bay grows in swamps, bayheads, wet hammocks, wet pine flatwoods, and marl prairies. Swamp bay ranges from the Atlantic coastal plain of Delaware and Maryland in the north, south along the coastal plain to and throughout Florida, and then west along the Gulf coastal plain to southeastern Texas (Little 1979).

The Institute for Regional Conservation has an extensive database of the vascular flora of southern Florida natural areas (http://regionalconservation.org/ircs/database/database.asp), listing only Persea palustris, swamp bay, as present in Everglades National Park, Big Cypress National Preserve, Arthur R. Marshall Loxahatchee National Wildlife Refuge, Everglades and Francis S. Taylor Wildlife Management Area, Okaloacoochee Slough Wildlife Management Area, Picayune Strand State Forest, and Florida Panther National Wildlife Refuge.

Although much of the literature on Everglades vegetation refers to red bay, Persea borbonia (for example, Loveless, 1959; Gunderson 1994), including some recent publications (for example, Sklar and van der Valk, 2002a; Espinar and others, 2011), the tree present in Everglades tree islands is swamp bay, Persea palustris. 
The common names of Persea borbonia and Persea palustris also are spelled inconsistently in the literature. Most recent taxonomic treatments spell the name as two words, as in red bay and swamp bay (for example, Wofford, 1997; Wunderlin, 1998), but much of the literature, including the forestry-related literature, uses the convention of contracting the name as a single word, redbay and swampbay (for example, Little, 1979 ). In yet another permutation, Godfrey and Wooten (1981) spell the common name of Persea palustris as swamp-bay. In what seems to be a lack of consistency, the USDA PLANTS database (U.S. Department of Agriculture, 2014) uses the common name redbay for Persea borbonia and swamp bay for Persea palustris. Because there is no internationally recognized standard for common names, we use the convention of two words in this report.

Regardless of the name applied to the tree, the Persea commonly found in Everglades tree islands is of great cultural significance to the Miccosukee Tribe. Persea is an irreplaceable plant whose leaves and wood are used for ceremonial and medicinal purposes.

\section{Everglades Tree Islands}

The tree islands of the Everglades are a striking feature of the otherwise herbaceous wetland vegetation that stretches for miles and miles. These patches of woody vegetation occur in a wide range of shapes and sizes, but commonly they are small, more-or-less circular islands or much larger, elongated islands whose long axis is parallel to the direction of water flow. The organic soil surface is slightly higher than the surrounding marsh (Loveless, 1959).

Small tree islands, as small as several meters across, are present throughout the Everglades region. In the north, in Arthur R. Marshall Loxahatchee National Wildlife Refuge, they are called pop-up or battery islands because they form when blocks of peat break away and float to the surface during high water (Sklar and van der Valk, 2002b). Elsewhere, they generally are associated with localized elevations in the underlying limestone. These small tree islands also are known as bayheads. The term "bayhead" refers to seasonally flooded broadleaf forests growing on organic soil that include tree species with the common name "bay," such as swamp bay, sweet bay (Magnolia virginiana), and loblolly bay (Gordonia lasianthus) (Monk, 1968). Southern Florida bayheads do not include loblolly bay, whose distribution does not extend south of Lake Okeechobee, but have dahoon (Ilex cassine), wax myrtle (Myrica cerifera), Carolina willow (Salix caroliniana), cocoplum (Chrysobalanus icaco), and pond apple (Annona glabra) in addition to the bays (Olmsted and Armentano, 1997). Cocoplum and pond apple are tropical in distribution.

Much larger, elongated tree islands with the long axis oriented parallel to the direction of water flow are present throughout the core Everglades. The elongated tree islands often are described as teardrop-shaped or comet-shaped, with a blunt head on the upstream end and a tapering tail on the downstream end (Sklar and van der Valk, 2002a). In the northern Everglades (Loxahatchee National Wildlife Refuge) the large tree islands can elongate to nearly $1.6 \mathrm{~km}$ in length and are on shallow ridges of peat, vegetated by a more or less homogeneous stand of mostly dahoon (Stone and others, 2002). 
Farther south in the Everglades, in WCA 3 and Everglades National Park, the elongated tree islands can have a small area of relatively high elevation at the upstream end (or head) of the island that is associated with a localized bedrock high. The tallest trees grow here, often including tropical hardwood hammock species that are not as tolerant of flooding (Sah, 2004). Proceeding downstream of the head of the island, the woody vegetation becomes shorter and more sparse until it gradually blends into the surrounding marsh vegetation (Sklar and van der Valk, 2002; Sah, 2004). Olmsted and Armentano (1997) refer to the downstream part of these tree islands (the "tail" as opposed to the "head") as bayhead swamp forest. The woody species composition is the same as in bayheads, but the canopy is more open and there is an understory of herbaceous marsh plants, including sawgrass (Cladium jamaicense), southern cattail (Typha domingensis), arrowhead (Sagittaria spp.), and pickerelweed (Pontederia cordata). Buttonbush (Cephalanthus occidentalis) is a frequent shrubby associate. Swamp bay has a fairly broad tolerance of hydrologic conditions and may be found growing in the infrequently flooded head of a tree island all the way to the very wet tail (Olmsted and Armentano, 1997).

East of Shark Slough in the rocky glades area of Everglades National Park, numerous small tree islands on limestone outcrops are embedded in the short hydroperiod marl prairies. These tree islands have tropical hardwood species in the high areas and bayhead species, including swamp bay, in the wet margins (Loope and Urban, 1980).

Although swamp bay is described as the dominant species on the bayhead tree islands on deep peat in the northern Everglades (Loveless, 1959; Stone and others, 2002), its importance on tree islands elsewhere varies widely. Few quantitative data are available on forest composition in Everglades tree islands. Wetzel and others (2008) report on the "head" vegetation of 31 of the higher tree islands in WCAs 3A and 3B. They sampled 10 small circular plots ( $2 \mathrm{~m}$ in radius) in the head end of each tree island and recorded the cover of species at least $3 \mathrm{~m}$ tall. In this analysis, swamp bay was found in 7 of the 31 tree islands sampled. The most widespread species were Carolina willow and pond apple, which occurred in plots on 26 and 24 islands, respectively. Other common species that occurred on more than 7 tree islands were elderberry (Sambucus canadensis), buttonbush, strangler fig (Ficus aurea), cocoplum, dahoon, and wax myrtle. Swamp bay ranked 11th in mean cover (1.1 percent), and pond apple had the greatest mean cover ( 8.9 percent). The exotic Brazilian pepper (Schinus terebinthifolius), occurred in only five tree islands, but had mean cover of 2.4 percent.

Another study looked at 12 tree islands in WCA 3B and 4 tree islands in adjacent WCA 3A (BEM Systems, Inc., 2005). The study sampled a pair of $10 \times 10 \mathrm{~m}$ plots in the head and a pair of $10 \times 10 \mathrm{~m}$ plots in the tail of each tree island, recording tree stems with diameter at breast height (dbh) greater than $2.5 \mathrm{~cm}$. Swamp bay did not occur in the plots of five of the islands, and had its maximum density on a tree island in WCA 3B, where it contributed 38 of the total 113 hardwood stems ( 34 percent). The mean diameter of swamp bay stems ranged from about 4.5 to $9.5 \mathrm{~cm}$, and the mean heights ranged from about 3 to $6 \mathrm{~m}$. 


\section{Effects of Laurel Wilt Disease on Native Vegetation}

We can base our predictions of the effects of laurel wilt on Everglades tree islands on observations of laurel wilt infestations farther north, where the disease arrived earlier. Discussion of studies of the effects of laurel wilt disease should be viewed with a couple of cautionary notes. The first cautionary note is the issue of nomenclature of the trees in question. Although these studies all refer to Persea borbonia, they generally are using the broad definition that includes Persea palustris. In some cases, Persea palustris likely is included, and possibly is the sole species, in the study. The second cautionary note is the issue of tree death. It is not always possible to determine whether the described tree death is the actual death of an individual genet or merely the death of the stem and crown, with the possibility of surviving basal sprouts.

In 2006-07, Cameron and others (2008), recognizing the difficulty in distinguishing between red bay and swamp bay, surveyed for laurel wilt in red bay (in the broad sense) in Georgia. They sampled 188 plots examining trees of 1 in. dbh and larger and noting sprouts and seedlings $(<1$ in. dbh). They determined that counties closest to the point of introduction of the redbay ambrosia beetle had the highest percentage of trees killed by laurel wilt, with the highest (71 percent) in Effingham County, located adjacent to Chatham County, home to Port Wentworth. Cameron and others (2008) also noted that areas with the most advanced infestation had the most stump sprouts, indicating that basal sprouting is a response to damage. They noted that there were many trees in the 1-4 in. diameter class that were still alive, even in heavily infected areas, although the largest trees generally were dead.

Fraedrich and others (2008) followed the mortality of what probably is red bay in the broad sense, based on habitat descriptions, in the Timucuan Ecological and Historical Preserve in northeastern Florida from July 2005 to January 2007. Dying trees had been observed there in autumn 2004. Each tree with primarily brown or wilting foliage was identified as dead, so it is possible that some of the "dead" trees actually were still alive basally. Large trees had more rapid and greater cumulative mortality. By January 2007, all trees with dbh greater than $10.2 \mathrm{~cm}$ were dead, whereas trees with $2.5-5.1 \mathrm{~cm}$ dbh had an 80 -percent mortality rate (fig. 1). Other findings in this study include sized-based bias of stem death, with only one death occurring among 222 red bay stems smaller than $2.5 \mathrm{~cm}$ dbh during the 2006-07 sample period. Some of the surviving trees have basal sprouts.

Goldberg and Heine (2009) sampled Persea borbonia (probably in the strict sense) in a maritime hammock dominated by live oak (Quercus virginiana) on Little Talbot Island in northeastern Florida. They observed that 38 percent of the red bay trees were dead and, contrary to other studies, that the mean diameter of the live trees $(16.6 \pm 2.0 \mathrm{~cm})$ was greater than that of the dead trees $(11.9 \pm 1.6 \mathrm{~cm})$. However, they noted that most of the live trees showed signs of the disease (dead and hanging leaves and beetle entrance holes) and, therefore, might have been classified as dead using the criteria of Fraedrich and others (2008). 




Figure 1. Graph showing cumulative percentage (\%) of red bay mortality by diameter class (diameter at breast height) on five 0.08-hectare plots at Fort George Island, Florida, July 2005-January 2007 (from Fraedrich and others, 2008, fig. 2).

Spiegel (2010) examined red bay in the broad sense in Georgia, noting that some of the sites examined had swamp bay (sites listed as bay swamp or Carolina bay). She sampled five sites that were infested with laurel wilt and three control sites where laurel wilt was not present. She found that 92 percent of the bay trees with dbh greater than or equal to $3 \mathrm{~cm}$ were dead in the infested sites, and 20 percent were dead in the control sites. It is not clear why there were so many dead trees in the control sites. However, there was no difference in the proportion of live red bays between infected and control plots in the shrub layer ( $\mathrm{dbh}<3 \mathrm{~cm}$ and $>50 \mathrm{~cm}$ tall) or seedlings $(<50 \mathrm{~cm}$ tall), indicating that laurel wilt was having minimal effect on the smallest individuals. Spiegel (2010) also noted increased numbers of basal sprouts in trees infected with laurel wilt.

Shields and others (2011) reported on laurel wilt effects in northern Florida at a site where symptoms were first discovered in 2007. They established plots that contained red bay (in the broad sense, referencing Brendemuehl [1990] who combined swamp bay and red bay). The plots were measured in 2007-08 and resampled in 2009. Shields and others (2011) observed 2, 30 , and 100-percent red bay mortality in the seedling $(<1.2 \mathrm{~m}$ tall), sapling $(<10 \mathrm{~cm} \mathrm{dbh,} \geq 1.2 \mathrm{~m}$ tall) and overstory $(\geq 10 \mathrm{~cm} \mathrm{dbh})$ strata, respectively. The death of all overstory trees within 2 years is drastic, but extirpation may be avoided due to the greater survival of small-diameter stems. 
Evans and others (2013) followed the progression of laurel wilt disease on St. Catherine's Island, a Georgia barrier island, from 2004 to 2009. The site is located $50 \mathrm{~km}$ south of the point of the original introduction of laurel wilt. They did not distinguish between red bay and swamp bay, and it is not possible to discern if they are referring to red bay, swamp bay, or both because both species are present in maritime forests (Wofford, 1997). In addition to the fate of trees, Evans and others (2013) noted the fate of basal sprouts. They tracked the fate of 327 individual red bay and (or) swamp bay trees. By 2009, only 69 trees (21 percent) were still alive, but all but 7 of the living trees had dead main stems and were present only as basal sprouts (fig. 2). Based on the criteria used in other studies (for example, Shields and others, 2011), this equates to a 98percent mortality rate (stem mortality as compared to genet mortality).



Figure 2. Graph showing total number and status of live red bay genets sampled from six 1 -hectare forest plots on St. Catherine's Island, Georgia, 2004-09. Evans and others (2013, fig. 1) identified the following states that characterize the status of genets from the onset of infection through genet mortality: "state 1"main stem with leaf senescence of less than 25 percent and onset of epicormic and basal sprouting; "state 2"-main stem with leaf senescence of 25-99\% and continued epicormic and basal sprouting; "state 3"death of main stem, with basal sprouting; "dead"-death of genet. 
Evans and others (2013) is the only study that explicitly tracked the survival of basally sprouting individuals, but there is a confounding issue of heavy white-tailed deer browsing. They noted a distinct browse line throughout the island and an absence of any hardwood tree regeneration in the study area. They also recorded significant deer browsing on almost all red bay sprouts. Because herbivory by deer may increase mortality of sprouting individuals, it is possible that this study presents a more pessimistic scenario than would occur in situations without a large deer population.

\section{Prognosis for Swamp Bay and Everglades Tree Islands}

The uncertainty as to whether the species observed in the studies cited in the preceding sections of this report were red bay in the narrow sense or swamp bay probably is not too important when trying to predict what will happen to the tree islands in the Everglades. All the Persea present in the Everglades are what is now referred to as Persea palustris, swamp bay. Swamp bay and red bay are closely related, even if they are different species, and laboratory and greenhouse studies indicate that they interact in a similar way with both the insect vector and the pathogen (Fraedrich and others, 2008; Hannula and others, 2008; Brar and others, 2013).

It seems inevitable that the redbay ambrosia beetle eventually will reach all Everglades tree islands, although the isolation of individual tree islands might slow local dispersal. Laurel wilt disease is already confirmed for tree islands in the interior of WCA 3A (Rodgers and others, 2014), and there is no reason to expect that it will not reach all islands within a few years, given the rapid spread of the disease (Koch and Smith, 2008; Rodgers and others, 2014). Based on the studies in northern Florida and Georgia (for example, Shields and others, 2011; Evans and others, 2013), it seems likely that most, if not all, mature swamp bays will disappear from Everglades tree islands in the near future. It is uncertain whether smaller individuals or resprouts will remain. Mayfield and Brownie (2013) have shown experimentally that the redbay ambrosia beetle visually cues on large-diameter stems, and that may partially explain the greater survival rates of smaller individuals seen in some studies. The basal sprouting of swamp bays possibly will allow existing genets to survive for an extended period, much like the American chestnut continues to survive as small resprouts several decades after all mature trees were killed (Freinkel, 2007). One possible concern, however, is that plants surviving only with basal sprouts may be more susceptible to flooding-induced mortality than healthy individuals because the live tissue may be completely inundated and the plants starved for oxygen.

There are numerous possible ecosystem responses to the loss of mature swamp bays, none of which are mutually exclusive. The immediate effect of wilt-induced tree mortality is to reduce root competition with adjacent individual trees. The fact that swamp bays killed by the laurel wilt retain their leaves for a prolonged period (Mayfield and others, 2011) means that there is no abrupt increase in light availability that normally would follow tree death. The death of the tree should result in a fairly short-term pulse of elevated nutrient release from the dead tissues. If the swamp bay is still alive basally, the nutrients may be captured and incorporated in the resprouts; otherwise, they become available for other species. 
If the swamp bays are present as scattered individuals, the canopy gaps possibly could be filled by the ingrowth of surrounding individuals of other species. The gaps also could be filled by advance regeneration or immigration of propagules from native tree species. Another response could be the coverage of the site by exotic tree species, such as Schinus or Melaleuca (Armentano and others, 2002; Brandt and others, 2002). The arrival of Schinus is more likely because of avian dispersal of propagules and the use of dead swamp bays as perches. The standing dead swamp bays also could serve as support for various vines, including the non-native Old World climbing fern (Lygodium microphyllum) (Brandt and Black, 2001; Fujisaki and others, 2010). According to Cameron and others (2008), the trees killed by laurel wilt tend to break up and fall apart within 2 years of dying, so they would only provide short-term support for other plants.

Laurel wilt disease is a species-specific disturbance in Everglades tree islands. Tree islands also are subject to many types of generalized disturbances. Excessive flooding has been responsible for the destruction of many Everglades tree islands (Sklar and van der Valk, 2002b; Wetzel and others, 2005) when flooding exceeds the tolerances of constituent tree species (Jones and others, 2006). Fire can have minor or major effects on tree islands, depending on moisture conditions (Wade and others, 1980; Armentano and others, 2002; Ruiz and others, 2013). Fires that do not consume organic soils normally would only kill the aboveground portion of trees, and most tree-island species (swamp bay included) can resprout from live stems or belowground tissues. If there is significant consumption of organic soil, trees are killed outright because their roots are killed and the site is opened for early successional species. Hurricanes also affect all tree-island species and swamp bays are particularly prone to bole breakage (Ugarte and others, 2006). Although there exists some interspecific variation in tolerance to flooding, fire, and high winds, the difference in responses of tree-island species to cold is much more pronounced, with temperate species such as swamp bay, wax myrtle, and dahoon undamaged by freezing temperatures, and tropical species such as cocoplum and pond apple severely damaged by freezing temperatures (Olmsted and others, 1993). Tropical species affected by cold temperatures generally are not killed outright and are able to survive by resprouting from stems or below ground parts, much like many woody plants do after fires.

Because swamp bay generally does not dominate Everglades tree islands, the mortality rate owing to laurel wilt disease should not markedly increase the risk of wildfire as can occur in low-diversity coniferous forests after insect attack (Jenkins and others, 2008; Hicke and others, 2012). However, on the relatively few tree islands in which swamp bay is a major component, the dead foliage retained in the canopy after attack by the redbay ambrosia beetle possibly could increase fire risk or severity for a year or more. 
The loss of mature swamp bays from tree islands would mean no flowering or fruit production and, therefore, reduced food availability for frugivorous wildlife species such as birds and mammals (Brendemuehl, 1990; Mayfield and others, 2011). The loss of foliage would be most significant to insect species for which Persea is a host plant. The larvae of the palamedes swallowtail (Papilio palamedes) feed only on members of the laurel family (Lauraceae) (Hall and Butler, 2013). Much less charismatic than the butterfly, the red bay psyllid (Trioza magnolia) causes leaf galls and is host-specific on Persea in the Southeast (red bay, swamp bay, and silk bay) (Hall, 2009). If swamp bay genets survive by basal sprouting, there may be enough leaves to sustain these insect species. However, foliage of sprouts may be more accessible than foliage of mature trees to a generalist herbivore such as white-tailed deer, and may sustain high rates of herbivory that could lead to increased genet mortality.

Because small individuals and possibly resprouting larger plants seem to be able to survive in areas infested by laurel wilt disease (Fraedrich and others, 2008; Spiegel, 2010; Shields and others, 2011), swamp bay are unlikely to become extinct in Everglades tree islands anytime soon. It would be prudent, however, to establish a monitoring program or to adapt existing monitoring to document the spread of laurel wilt disease throughout the Everglades and to follow individual plants to see if any individuals are resistant to the disease and if resprouting plants survive. If larger trees are destined to be killed by laurel wilt, the return of mature swamp bays to Everglades tree islands will await either a biological control of the insect vector or the fungal pathogen, or the emergence of a disease-resistant genotype of swamp bay.

\section{Acknowledgments}

Funding for this project was provided by the U.S. Geological Survey Office of Tribal Relations. Rory Feeney, Fish and Wildlife Director, Miccosukee Tribe of Indians of Florida, provided a site visit to tree islands in Water Conservation Area 3A. 


\section{References Cited}

Armentano, T.V., Jones, D.T., Ross, M.S., and Gamble, B.W., 2002, Vegetation pattern and process in tree islands of the southern Everglades and adjacent areas, chap. 8 of Sklar, F.H., and van der Valk, A., eds., Tree islands of the Everglades: Dordrecht, The Netherlands, Kluwer Academic Publishers, p. 225-281.

Aukema, J.E., McCullough, D.G., Von Holle, B., Liebhold, A.M., Britton, K., and Frankel, S.J., 2010, Historical accumulation of nonindigenous forest pests in the continental United States: BioScience, v. 60, p. 886-897.

BEM Systems, Inc., 2005, Tree island characterization in Water Conservation Area 3-Final report: Prepared by BEM Systems, Inc., for South Florida Water Management District, West Palm Beach, Florida.

Brandt, L.A., and Black, D.W., 2001, Impacts of the introduced fern, Lygodium microphyllum, on the native vegetation of tree islands in the Arthur R. Marshall Loxahatchee National Wildlife Refuge: Florida Scientist, v. 64, p. 191-196.

Brandt, L.A., Silveira, J.E., and Kitchens, W.M., 2002, Tree islands of the Arthur R. Marshall Loxahatchee National Wildlife Refuge, chap. 10 of Sklar, F.H., and van der Valk, A., eds., Tree islands of the Everglades: Dordrecht, The Netherlands, Kluwer Academic Publishers, p. 311-335.

Brar, G.S., Capinera, J.L., Kendra, P.E., McLean, S., and Peña, J.E., 2013, Life cycle, development, and culture of Xyleborus glabratus (Coleoptera: Curculionidae: Scolytinae): Florida Entomologist, v. 96, p. 1,158-1,167.

Brendemuehl, R.H., 1990, Persea borbonia (L.) Spreng., Redbay. in Burns, R.M., and Honkala, B.H., eds., Silvics of North America, Volume 2-Hardwoods: U.S. Department of Agriculture, U.S. Forest Service, Agricultural Handbook 654.

Cameron, R.S., Bates, C., and Johnson, J., 2008, Distribution and spread of laurel wilt disease in Georgia-2006-08 survey and field observations: Georgia Forestry Commission, 29 p.

Coder, K.D., 2007, Taxonomy and identification-Redbay (Persea borbonia): Athens, University of Georgia, Warnell School of Forestry and Natural Resources, Outreach Publication SFNR07-2 $10 \mathrm{p}$.

Correll, D.S., and Correll, H.B., 1982, Flora of the Bahama Archipelago: Vaduz, Liechtenstein, A.R.G. Gantner Verlag K.-G.

Espinar, J. L., Ross, M.S., and Sah, J.P., 2011. Pattern of nutrient availability and plant community assemblage in Everglades tree islands, Florida, USA: Hydrobiologia, v. 667, p. 89-99.

Evans, J.P., Scheffers, B.R., and Hess, M., 2013, Effect of laurel wilt invasion on redbay populations in a maritime forest community: Biological Invasions, doi: 10.1007/s10530-0130592-y.

Fraedrich, S.W., Harrington, T.C., Rabaglia, R.J., Ulyshen, M.D., Mayfield, A.E., III, Hanula, J.L., Eickwort, J.M., and Miller, D.R., 2008, A fungal symbiont of the redbay ambrosia beetle causes lethal wilt in redbay and other Lauraceae in the southeastern United States: Plant Disease, v. 92, p. 215-224.

Freinkel, S., 2007, American chestnut—The life, death, and rebirth of a perfect tree: Berkeley, University of California Press.

Fujisaki, I., Brandt, L.A., Chen, H., and Mazzotti, F.J., 2010, Colonization, spread, and growth of Lygodium microphyllum on tree islands in a wetland in Florida: Invasive Plant Science and Management, v. 3, p. 412-420. 
Godfrey, R.K., and Wooten, J.W., 1981, Aquatic and wetland plants of southeastern United States-Dicotyledons: Athens, University of Georgia Press.

Goldberg, N., and Heine, J., 2009, A comparison of arborescent vegetation pre- (1983) and post(2008) outbreak of the invasive species the Asian ambrosia beetle Xyleborus glabratus in a Florida maritime hammock: Plant Ecology and Diversity, v. 2, p. 77-83.

Gunderson, L.H., 1994, Vegetation of the Everglades - Determinants of community composition, in Davis, S.M., and Ogden, J.C., eds., Everglades - The ecosystem and its restoration: Delray Beach, Florida, St. Lucie Press, p. 323-340.

Hall, D.W., 2009, Red bay psyllid, Trioza magnoliae (Ashmead) (Insecta: Hemiptera: Sternorrhyncha: Psyllidae): Gainesville, University of Florida, IFAS Extension, publication number EENY-438.

Hall, D.W., and J.F. Butler, 2013, Palamedes swallowtail, laurel swallowtail, Papilio palamedes (Drury) (Insecta: Lepidoptera: Papilionidae): Gainesville, University of Florida, IFAS Extension, publication number EENY-060.

Hanula, J.L., Mayfield, A.E., III, Fraedrich, S.W., and Rabaglia, R.J., 2008, Biology and host associations of redbay ambrosia beetle (Coleoptera: Curculionidae: Scolytinae), exotic vector of laurel wilt killing redbay trees in the southeastern United States: Journal of Economic Entomology, v. 101, p. 1,276-1,286.

Harrington, T.C., Fraedrich, S.W., and Aghayeva, D.N., 2008, Raffaelea lauricola, a new ambrosia beetle symbiont and pathogen on the Lauraceae: Mycotaxon, v. 104, p. 399-404.

Hicke, J.A., Johnson, M.C., Hayes, J.L., and Preisler, H.K., 2012, Effects of bark beetle-caused tree mortality on wildfire: Forest Ecology and Management, v. 271, p. 81-90.

Hulcr, J., and Dunn, R.R., 2011, The sudden emergence of pathogenicity in insect-fungus symbioses threatens naive forest ecosystems: Proceedings of the Royal Society B, v. 278, p. 2,866-2,873.

Jenkins, M.J., Hebertson, E., Page, W., and Jorgensen, C.A., 2008, Bark beetles, fuels, fires and implications for forest management in the Intermountain West: Forest Ecology and Management, v. 254, p. 16-34.

Jones, D.T., Sah, J.P., Ross, M.S., Oberbauer, S.F., Hwang, B., and Jayachandran, K., 2006, Responses of twelve tree species common in Everglades tree islands to simulated hydrologic regimes: Wetlands, v. 26, p. 830-844.

Kendra, P.E., Montgomery, W.S., Niogret, J., and Epsky, N.D., 2013, An uncertain future for American Lauraceae-A lethal threat from redbay ambrosia beetle and laurel wilt disease (a review): American Journal of Plant Sciences, v. 4, p. 727-738.

Koch, F.H., and Smith, W.D., 2008, Spatio-temporal analysis of Xyleborus glabratus (Coleoptera: Circulionidae: Scolytinae) invasion in eastern U.S. forests: Environmental Entomology, v. 37, p. 442-52.

Liebhold, A.M., MacDonald, W.L., Bergdahl, D., and Mastro, V.C., 1995, Invasion by exotic forest pests-A threat to forest ecosystems: Forest Science Monographs, v. 30, p. 1-58.

Little, E.L., 1979, Checklist of United States trees (native and naturalized): U.S. Department of Agriculture, U.S. Forest Service, Handbook 541.

Long, R.W., and Lakela, O., 1976. A flora of tropical Florida-A Manual of the seed lants and ferns of southern peninsular Florida: Miami, Florida, Banyan Books. 
Loope, L.L., and Urban, N.H., 1980, A survey of fire history and impact in tropical hardwood hammocks in the east Everglades and adjacent portions of Everglades National Park: National Park Service, South Florida Research Center Report T-592, Everglades National Park, Homestead, Florida.

Loveless, C.M. ,1959, A study of the vegetation in the Florida Everglades: Ecology, v. 40, p. 19.

Mayfield, A.E., III, 2007, Laurel wilt-A serious threat to redbay and other related native plants: Palmetto, v. 24, p. 8-11.

Mayfield, A.E., III, and Brownie, C., 2013, The redbay ambrosia beetle (Coleoptera: Curculionidae: Scolytinae) uses stem silhouette diameter as a visual host-finding cue: Environmental Entomology, v. 42, p. 743-750.

Mayfield, A.E., III, Crane, J.H., and J.A. Smith, 2011, Laurel wilt-A threat to redbay, avocado and related trees in urban and rural landscapes: Gainesville, University of Florida, Horticultural Sciences Department, Florida Cooperative Extension Service, Institute of Food and Agricultural Sciences, publication number HS1137.

Monk, C.D., 1968, Successional and environmental relationships of the forest vegetation of north central Florida: American Midland Naturalist, v. 79, p. 441-457.

Nelson, G., 1994, The trees of Florida-A reference and field guide: Sarasota, Florida, Pineapple Press.

Olmsted, I., and Armentano, T.V., 1997, Vegetation of Shark Slough, Everglades National Park: National Park Service SFNRC Technical Report 97-001, Everglades National Park, Homestead, Florida.

Olmsted, I., Dunevitz, H., and Platt, W.J., 1993, Effects of freezes on tropical trees in Everglades National Park Florida, USA: Tropical Ecology, v. 34, p. 17-34.

Radford, A.E., Ahles, H.E., and Bell., C.R., 1968, Manual of the vascular flora of the Carolinas: Chapel Hill, University of North Carolina Press.

Rodgers, L., Derksen, A., and Pernas, T., 2014, Expansion and impact of laurel wilt in the Florida Everglades: Florida Entomologist, v. 97, p. 1247-1250.

Ruiz, P.L., Sah, J.P., Ross, M.S., and Spitzig, A.A., 2013, Tree island response to fire and flooding in the short-hydroperiod marl prairie grasslands of the Florida Everglades, USA: Fire Ecology, v. 9, p. 38-54.

Sah, J.P., 2004, Vegetation structure and composition in relation to the hydrological and soil environments in Shark Slough, chap. 6 of Ross, M.S., and Jones, D.T., eds., Tree islands in the Shark Slough landscape-Interactions of vegetation, hydrology, and soils-Final Report: Florida International University, Southeast Environmental Research Center Report No. EVER 00075, submitted to National Park Service, Everglades National Park.

Shields, J., Jose, S., Freeman, J., Bunyan, M., Celis, G., Hagan, D., Morgan, M., Pieterson, E.C., and Zak, J., 2011, Short-term impacts of laurel wilt on redbay (Persea borbonia [L.] Spreng.) in a mixed evergreen-deciduous forest in northern Florida: Journal of Forestry, v. 109, p. 8288.

Sklar, F.H., and van der Valk, A., eds., 2002a, Tree islands of the Everglades: Dordrecht, The Netherlands, Kluwer Academic Publishers.

Sklar, F.H., and van der Valk, A., eds., 2002b, Tree islands of the Everglades-An overview, chap. 1 of Sklar, F.H., and van der Valk, A., eds., Tree islands of the Everglades: Dordrecht, The Netherlands, Kluwer Academic Publishers, p. 1-18. 
Spiegel, K.S., 2010, Impacts of laurel wilt disease on redbay (Persea borbonia) population structure and forest communities in the coastal plain of Georgia: Statesboro, Georgia Southern University, Master's thesis.

Stone, P.A., Gleason, P.J., and Chmura G.L., 2002, Bayhead tree islands on deep peats of the northeastern Everglades, chap. 3 of Sklar, F.H., and van der Valk, A., eds., Tree islands of the Everglades: Dordrecht, The Netherlands, Kluwer Academic Publishers, p. 71-115.

Ugarte, C.A., Brandt, L.A., Melvin, S, Mazzotti, F.J., and Rice, K.G., 2006, Hurricane impacts to tree islands in Arthur R. Marshall Loxahatchee National Wildlife Refuge, Florida:

Southeastern Naturalist, v. 5, p. 737-746.

U.S. Department of Agriculture, 2014, USDA PLANTS database: U.S. Department of Agriculture, Natural Resources Conservation Service database, National Plant Data Team, Greensboro, North Carolina, http://plants.usda.gov.

Wade, D., Ewel, J., and Hofstetter, R., 1980, Fire in south Florida ecosystems: U.S. Department of Agriculture, U.S. Forest Service, Southeastern Forest Experiment Station, Asheville, North Carolina, General Technical Report SE-17.

Wetzel, P.R., Pinion, T., Towles, D.T., and Heisler, L., 2008, Landscape analysis of tree island head vegetation in Water Conservation Area 3, Florida Everglades: Wetlands, v. 28, p. 276289.

Wetzel, P.R., van der Valk, A.G., Newman, S., Gawlik, D.E., Gann, T.T., Coronado-Molina, C,A, Childers, D.L., and Sklar, F.H., 2005, Maintaining tree islands in the Florida Everglades-Nutrient redistribution is the key: Frontiers in Ecology and the Environment, v. 3, p. 370-376.

Wofford, B.E., 1997, Persea, in Flora of North America Editorial Committee, eds., Flora of North America north of Mexico, Vol. 3: New York and Oxford, http://www.efloras.org/florataxon.aspx?flora_id=1\&taxon_id=124627.

Wunderlin, R.P., and Hansen, B.F., 2008, Atlas of Florida vascular plants: Tampa, University of South Florida, Institute for Systematic Botany, http://www.florida.plantatlas.usf.edu.

Wunderlin, R.P., 1998, Guide to the vascular plants of Florida: Gainesville, University Press of Florida. 


\section{Photographs}

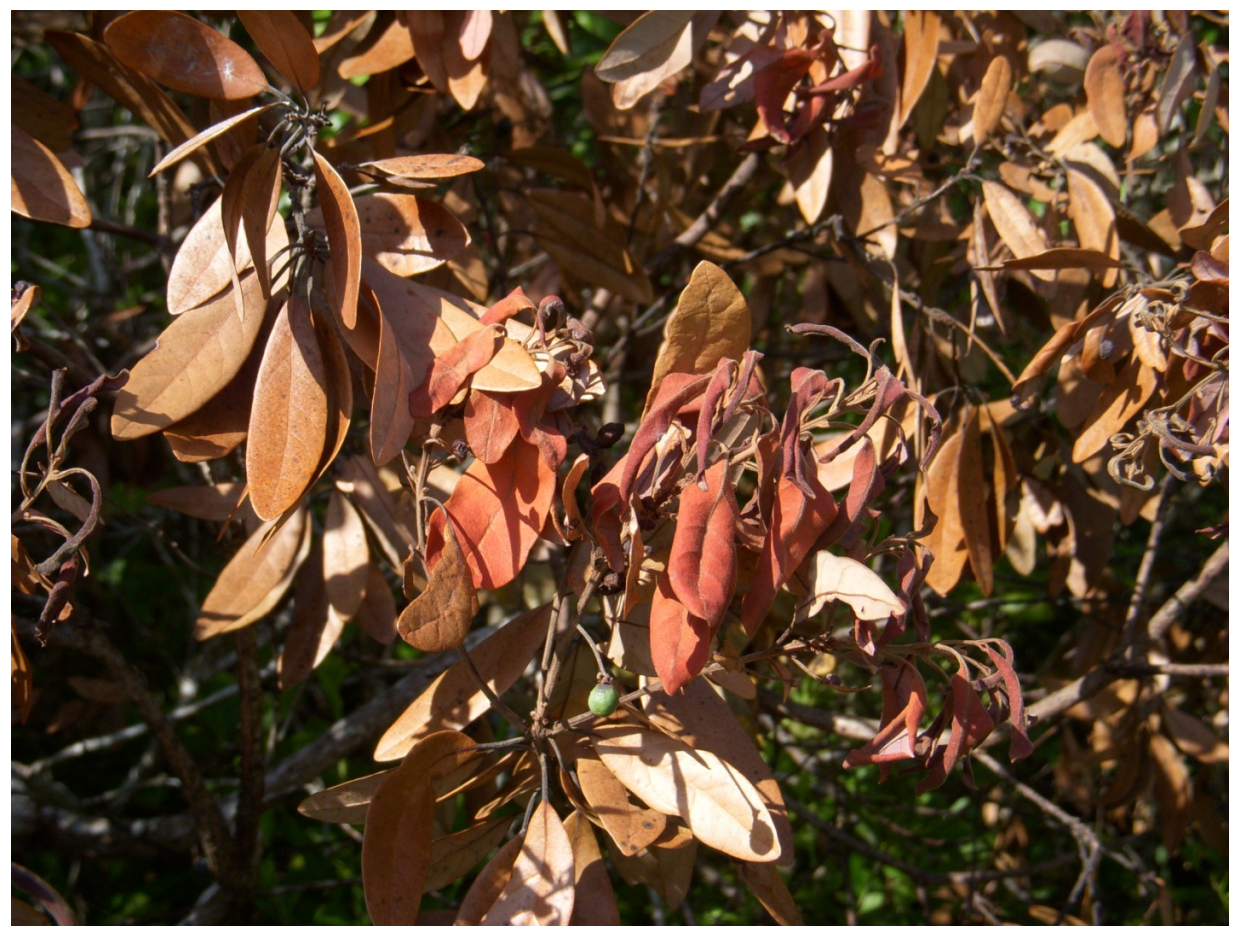

Swamp bay killed by laurel wilt, Big Cypress National Preserve, southern Florida, August 8, 2013.

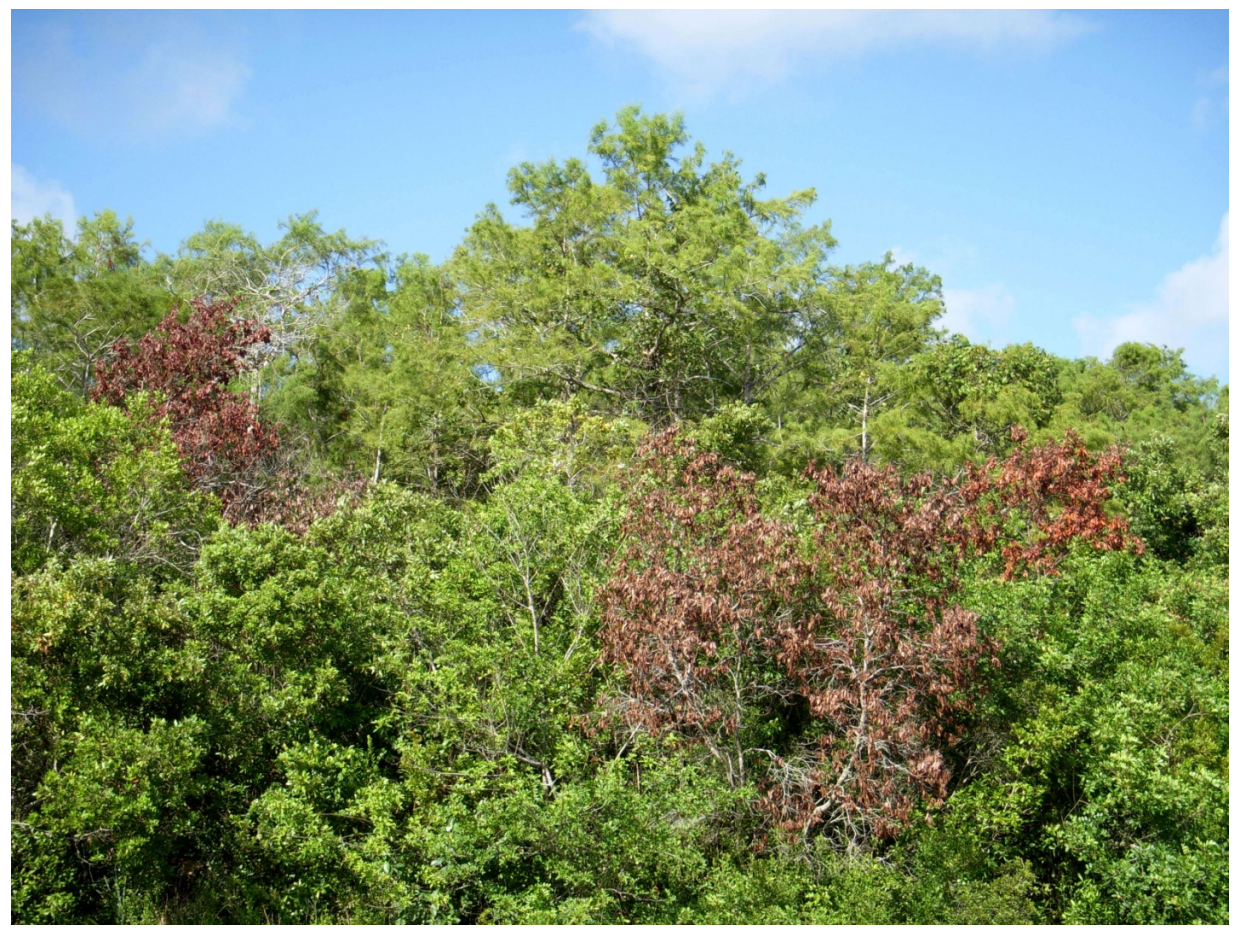

Swamp bays killed by laurel wilt along Jetport road, Big Cypress National Preserve, southern Florida, August 8, 2013. 




Swamp bay killed by laurel wilt along Tamiami Trail canal, Big Cypress National Preserve, southern Florida, January 28, 2014. 


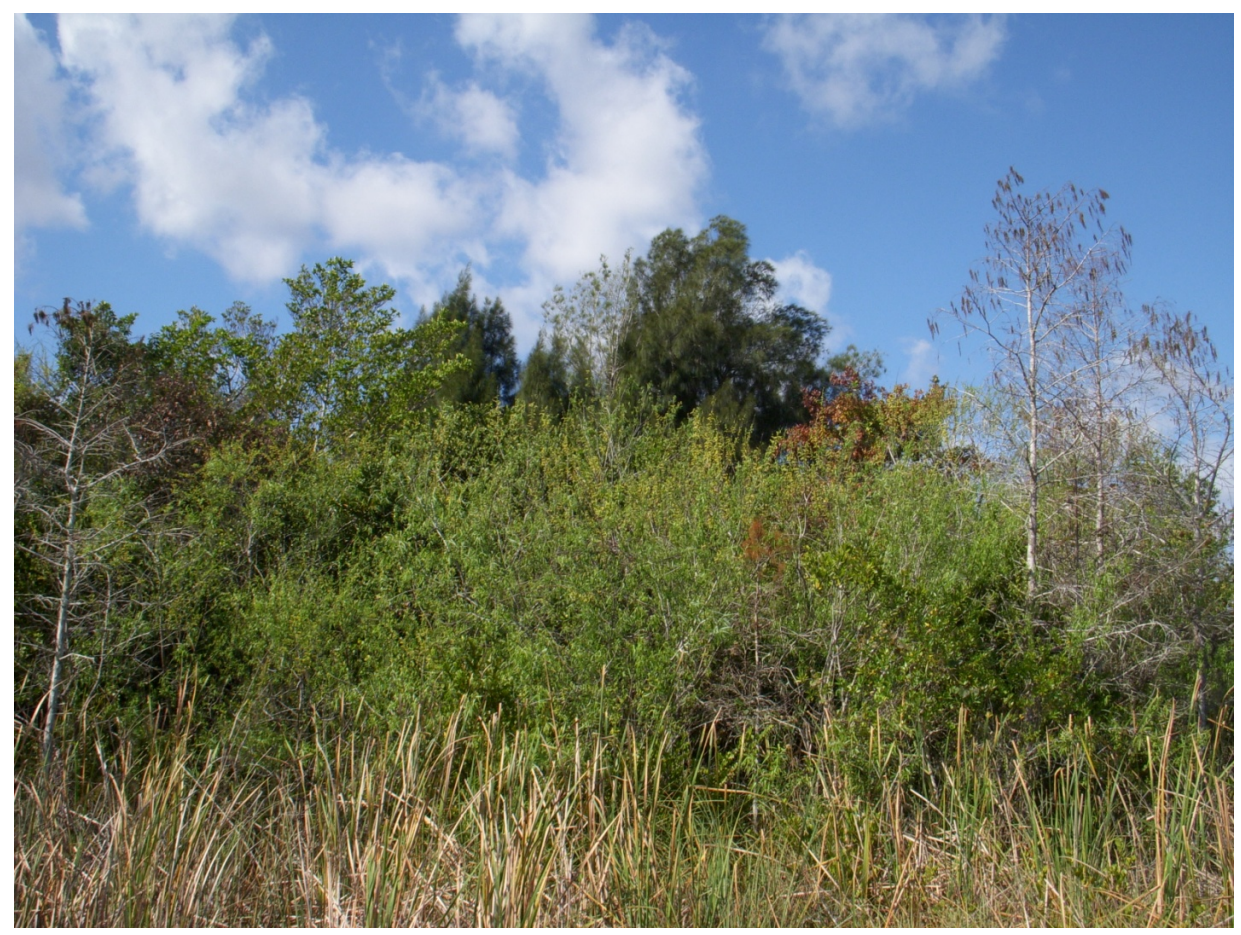

Cultural tree island in southwestern corner of Water Conservation Area 3A, southern Florida, January 28,2014 . One dead swamp bay is visible on left behind leafless cypress, and another one is visible to right of tall Australian pine. (UTM coordinates are $17 \mathrm{R} 516720 \mathrm{E}$ and $2855210 \mathrm{~N}$.) 


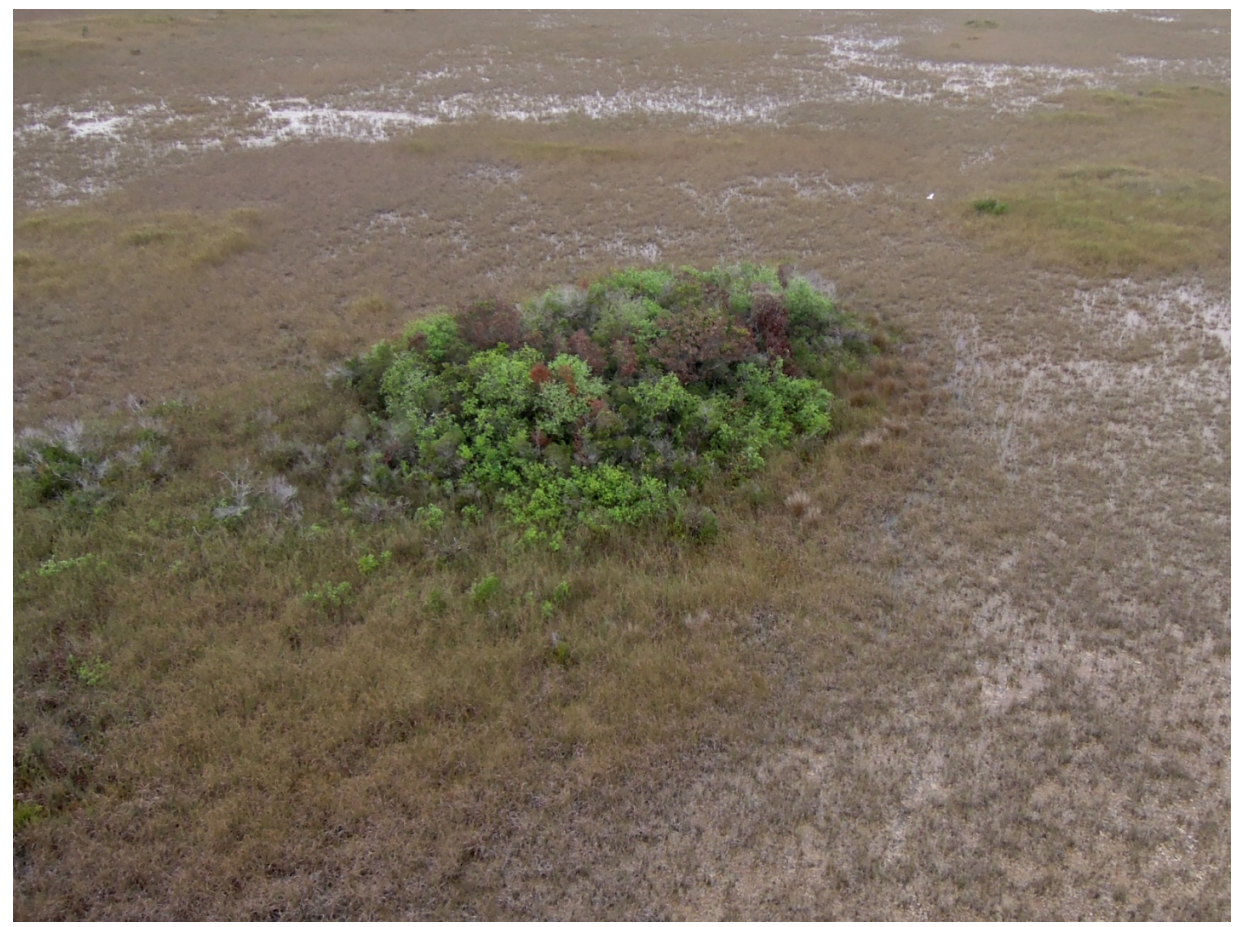

Bayhead tree island in Shark River Slough with laurel wilt-killed swamp bays, Everglades National Park, southern Florida, February 12, 2014. Photograph courtesy of Tony Pernas, National Park Service.

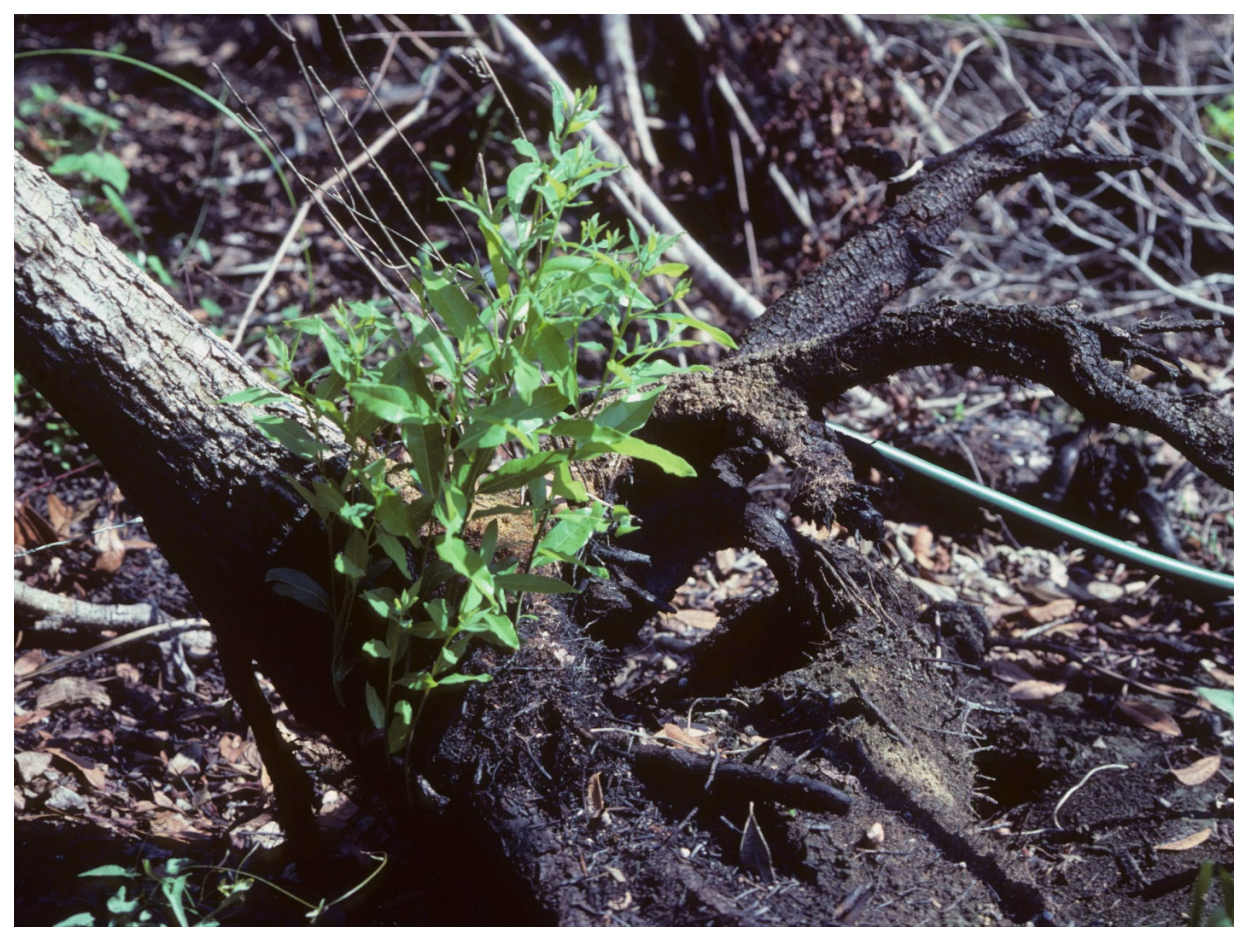

Swamp bay sprouting after wildfire in East Everglades tree island, southern Florida, July 1, 1981. 
Publishing support provided by the U.S. Geological Survey Publishing Network, Tacoma Publishing Service Center

For more information concerning the research in this report, contact the Director, Southeast Ecological Science Center

U.S. Geological Survey

7920 NW 71st Street

Gainesville, Florida 32653

http://fl.biology.usgs.gov/ 


\section{हू}

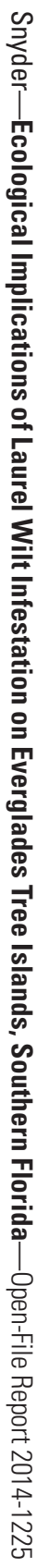

